\title{
Selective Policy Imigrasi Indonesia terhadap Orang Asing dari Negara Calling Visa
}

\author{
Junior Perdana Sande \\ Kantor Imigrasi Kelas I Khusus TPI Soekarno-Hatta
}

\begin{abstract}
This article aims to analyze the selective policy adopted by Indonesian immigration towards foreigners from calling visa countries. Through a qualitative research method with a descriptive analysis approach and the framework of concept of foreign policy decision making and national interests, it can be explained how the implementation of Indonesian immigration selective policy and the determination of vulnerable countries so they can be categorized in to calling visa countries. The author also seeks to provide an analysis of the anomalies in determining countries that are categorized as calling visa countries. The application of selective policy applied by the Indonesian government through the issuance of visiting permits, supervision, and immigration administrative actions against any foreigner. It is implemented more stringently and through a multi-layered process towards foreigners from calling visa countries.
\end{abstract}

Keywords: selective policy, immigration, calling visa, foreigner

\begin{abstract}
Abstrak
Artikel ini bertujuan untuk menganalisa kebijakan selektif yang diterapkan oleh imigrasi Indonesia terhadap orang asing dari negara calling visa. Melalui metode penelitian kualitatif dengan pendekatan deskriptif analisis dan kerangka konsep foreign policy decision making dan kepentingan nasional dapat dijelaskan bagaimana bentuk penerapan kebijakan selektif imigrasi Indonesia dan penentuan negara tertentu yang dianggap rawan sehingga masuk dalam kategori calling visa. Penulis juga berupaya untuk memberi analisis tentang anomali dalam penentuan negara yang masuk dalam kategori negara calling visa. Penerapan kebijakan selektif diberlakukan oleh pemerintah Indonesia melalui pemberian izin berkunjung, pengawasan, dan tindakan administrasi keimigrasian terhadap setiap orang asing. Kebijakan selektif dilaksanakan dengan lebih ketat dan melalui proses berlapis terhadap orang asing yang berasal dari negara caling visa.
\end{abstract}

Kata-kata kunci: kebijakan selektif, imigrasi, calling visa, orang asing 


\section{Pendahuluan}

Era globalisasi berkembang dengan sangat pesat. Globalisasi merupakan sebuah fenomena integrasi internasional yang terdiri dari berbagai aspek meliputi dimensi ekonomi, sosial, politik, teknologi, dan budaya (Mir, Hassan, \& Qandri, 2014:607). Perkembangan era globalisasi telah mempengaruhi segala segi kehidupan dan pergaulan setiap aktor hubungan internasional baik individu, kelompok kepentingan, organisasi internasional, maupun negara, tanpa terkecuali. Walaupun globalisasi yang timbul sebagai dampak dari berkembangnya era teknologi informasi dan komunikasi merupakan fenomena yang relatif baru beberapa dekade terakhir, beberapa ahli justru berpendapat bahwa globalisasi merupakan sebuah proses yang telah berlangsung selama ribuan tahun (Steger, 2003).

Pesatnya perkembangan era globalisasi membuat pergaulan dan kerjasama antar negara semakin meningkat dan intens. Batas-batas negara semakin menipis yang diakibatkan oleh makin tingginya tingkat ketergantungan antar negara dan pergaulan internasional yang semakin terintegrasi ( $\mathrm{Li}, 2008)$. Aliran dana dan modal melalui perdagangan dan investasi, nilai-nilai demokrasi, produk kultural, dan media juga semakin meningkat. Di atas semua itu, perpindahan orang atau migrasi antar negara semakin tidak terbendung (Castles, De Hass \& Miller, 2014:33). Tren migrasi yang terjadi berubah-ubah seiring dengan perkembangan zaman yang memberikan pengaruh timbal balik. Kondisi ini dikaitkan dengan teori sistem migrasi dimana perpindahan migran yang disertai juga dengan perpindahan ide, barang, dan modal, ke suatu negara cenderung akan menghasilkan aliran balik (counterflows) dalam jangka menengah dan panjang (Czaika \& de Hass dalam Romdiati, 2015:91).

Aktivitas migrasi internasional menunjukan peran penting negara. Negara berperan sebagai fasilitator untuk mempermudah akses individu maupun kelompok untuk melakukan migrasi sesuai dengan kepentingan nasional negara masing-masing (Gusnelly, 2010:62). Meningkatnya arus migrasi antar negara baik untuk tujuan singkat serta untuk tujuan jangka panjang membuat setiap negara menerapkan aturan-aturan tertentu. Peraturan-peraturan yang dibuat oleh setiap negara dalam bidang imigrasi bisa bersifat mempermudah ataupun membatasi pola migrasi orang asing. Peraturan yang mempermudah seperti pembuatan kebijakan bebas visa kunjungan dan pengurangan prosedur atau proses yang harus dilakukan oleh orang asing jika ingin memasuki suatu negara tertentu, dengan tujuan untuk meningkatkan devisa ke dalam negaranya sebab migrasi merupakan sebuah proses yang berdampak secara ekonomi dalam berbagai aspek, tidak hanya pada negara asal orang asing tetapi juga negara tujuan (Azam \& Gubert, 2006). Adapun peraturan yang bersifat membatasi misalnya pembuatan kebijakan dan pengenaan syarat-syarat ketat yang cukup 
menyulitkan dan menghabiskan waktu relatif lama demi melindungi kepentingan nasional, kedaulatan, dan keamanan negara. Meningkatnya jumlah perpindahan manusia juga meningkatkan presentasi kejahatan lintas batas negara (transnational crimes) seperti terorisme lintas negara, pembajakan, cyber crime, human trafficking, human smuggling, money laundry, serta penyelundupan obat-obat terlarang dan senjata api. Jika dibiarkan, bentuk-bentuk kejahatan tersebut tidak hanya berdampak bagi keamanan negara, tetapi juga akan mempengaruhi keamanan masyarakat dan individu dalam negeri (human security).

Sebagai dampak dari Masyarakat Ekonomi Asean (MEA), Negara Indonesia banyak didatangi oleh orang asing. Direktorat Jenderal Imigrasi, Kementerian Hukum dan Hak Asasi Manusia (Kemenkumham) Republik Indonesia, menyatakan bahwa berdasarkan data perlintasan manusia pada periode Januari-Juni 2017, Ditjen Imigrasi telah melayani perlintasan sebanyak 19.089.288 orang (Tribun News, 2017). Jika dibandingkan dengan data perkembangan pariwisata nasional dari Badan Pusat Statistik (BPS) Indonesia periode Januari-November 2018, jumlah wisatawan mancanegara yang datang ke Indonesia mencapai 14,39 juta atau naik 11,63 persen dibandingkan periode yang sama tahun sebelumnya yakni sekitar 12,89 juta (Detik Finance, 2019). Orang asing yang datang ke Indonesia tersebut tidak hanya berasal dari negara yang memiliki tingkat keamanan dan ekonomi yang relatif stabil, tetapi juga berasal dari negara-negara yang memiliki tingkat kerawanan tertentu atau tidak stabil ditinjau dari aspekaspek tertentu.

Tingginya jumlah orang asing yang memasuki wilayah negara Indonesia menuntut Pemerintah Indonesia untuk mengadaptasi kebijakankebijakan tertentu agar dampak negatif yang timbul dari arus migrasi tersebut bisa diminimalisir. Pemerintah Indonesia menyeleksi orang asing mana saja yang boleh memasuki wilayah negara Indonesia melalui kebijakan yang selektif (selective policy). Tidak semua orang asing akan diizinkan masuk ke dalam wilayah negara Indonesia. Selective policy ini akan diterapkan dengan lebih selektif kepada setiap orang asing yang berasal dari negara-negara rawan. Setiap negara memiliki istilah masingmasing dalam mengkategorikan negara rawan tersebut. Dalam istilah keimigrasian Indonesia, negara-negara yang memiliki tingkat kerawanan tertentu disebut sebagai negara calling visa. Berdasarkan permasalahan di atas, artikel ini akan membahas bagaimana penerapan kebijakan selektif (selective policy) imigrasi indonesia terhadap orang asing yang berasal dari negara calling visa.

Belum adanya penelitian yang secara spesifik membahas mengenai kebijakan selektif imigrasi Indonesia jika dikaitkan dengan orang asing dari negara calling visa menyebabkan penulis tertarik untuk mengangkat topik 
ini. Akan tetapi, telah ada beberapa tulisan mengenai kebijakan selektif imigrasi Indonesia secara umum atau dikaitkan dengan aspek dan konsep lain. Syahrin (2016) menulis mengenai kedaulatan negara dalam perspektif keimigrasian. Dalam tulisan tersebut Syahrin mengungkapkan bahwa Negara Indonesia menerapkan eksistensi kedaulatan dalam perspektif keimigrasian dikaitkan dengan kebijakan selektif keimigrasian. Kebijakan selektif keimigrasian merupakan salah satu konsep kedaulatan negara sebagai filter bagi setiap orang asing yang masuk dan keluar wilayah Negara Indonesia, dimana hanya orang asing yang dapat memberikan manfaat serta tidak membahayakan keamanan dan ketertiban, yang diberikan izin masuk dan keluar dari wilayah Negara Indonesia. Dalam tulisan lain, Arifin (2018) membahas mengenai penolakan orang asing ke Negara Indonesia melalui Tempat Pemeriksaan Imigrasi di bandara internasional, yang juga dikaitkan dengan konsep kedaulatan negara. Menurut Arifin, penolakan orang asing untuk masuk ke wilayah Negara Indonesia merupakan suatu bentuk kedaulatan Negara Indonesia yang absolut dan mutlak, dengan memprioritaskan pada pendekatan keamanan (security approach) dan kebijakan selektif (selective policy).

Tujuan dari penulisan ini adalah untuk mengetahui bagaimana prosedur kebijakan selektif jika diterapkan kepada warga negara dari negara calling visa dan mengetahui perbandingan jika prosedur kebijakan yang sama diterapkan kepada negara-negara diluar kategori negara calling visa. Dalam artikel ini, penulis menggunakan metode penelitian kualitatif di mana metode ini lebih menekankan pada penelitian yang bersifat deskriptif dan analisis. Metode yang digunakan dalam pengumpulan data adalah studi kepustakaan (library research). Pengumpulan data dilakukan untuk mendapatkan informasi yang sesuai dengan tujuan penelitian. Pengumpulan data dilakukan melalui dokumen dan literatur yang sesuai dengan variabel-variabel dalam penelitian ini. Dokumen dan literatur yang diperoleh terdiri dari dukumen primer seperti peraturan perundangundangan, peraturan pelaksana, dan ketetapan konvensi, serta dokumen sekunder yakni buku, majalah, dan artikel hasil penelitian sebelumnya.

Data-data yang telah diperoleh kemudian akan disortir atau dipilih untuk menjawab pertanyaan penelitian. Data yang telah dikumpulkan kemudian akan diolah dengan menggunakan metode dekriptif analitis, dijabarkan secara terperinci dan digabung dengan analisis-analis logis yang muncul pada tahap pemahaman data. Terakhir, penulis akan mengumpulkan hasil deskripsi dan analisis yang kemudian akan secara sistematis sehingga memungkinkan penarikan kesimpulan yang logis terhadap permasalahan dalam artikel ini. Penulis berpendapat bahwa walaupun tidak ada larangan bagi orang asing dari negara calling visa memasuki wilayah Negara Indonesia, tetapi syarat-syarat yang harus 
dipenuhi akan lebih berat dibandingkan dengan orang asing yang bukan berasal dari negara rawan. Penyeleksian orang asing sebagai perwujudan selective policy akan dibuat lebih ketat terhadap orang asing yang berasal dari negara-negara calling visa demi menjaga keamanan dan ketertiban dalam negeri yang mungkin akan mengalami masalah dengan masuknya warga asing tersebut.

Artikel ini akan ditulis dengan sistematika sebagai berikut. Bagian pertama akan menjabarkan konsep foreign policy decision making dan kepentingan nasional sebagai lantasan teoretis. Bagian kedua akan membahas mengenai kebijakan selektif (selective policy) yang menjadi dasar imigrasi Indonesia untuk menyeleksi orang asing yang hendak memasuki wilayah Negara Indonesia. Analisis konsep kepentingan nasional dalam bidang keimigrasian juga akan dijabarkan pada bagian ini. Bagian ketiga akan membahas mengenai penetapan kategori negara calling visa oleh Pemerintah Indonesia dan analisis dibalik penetapan negara-negara tersebut berdasarkan pembuatan keputusan luar negeri Negara Indonesia. Bagian keempat akan memberikan bahasan mengenai anomali penentuan negara calling visa dimana ada negara yang layak masuk kategori negara calling visa tetapi pada kenyataannya tidak masuk dalam negara calling visa, atau sebaliknya. Bagian kelima akan membahas bagaimana pemberian izin berkunjung kepada orang asing dari negara caling visa. Bagian keenam, yang merupakan bagian terakhir, akan membahas mengenai pengawasan orang asing yang berada di wilayah Negara Indonesia dan tindakan administrasi keimigrasian Indonesia bagi setiap orang asing yang melakukan pelanggaran keimigrasian, termasuk orang asing dari negara calling visa.

\section{Kerangka Konseptual}

Foreign Policy Decision Making

Foreign policy decision making merupakan sebuah model skema analisis yang digunakan untuk menelaah keputusan yang diambil oleh negara dalam dinamika hubungan internasional. Holsti (1983) berpendapat bahwa ketika berbicara mengenai perilaku negara, maka hal tersebut sebenarnya mengarah pada tindakan para pembuat kebijakan yang sedang melaksanakan pendefinisian tujuan, melakukan pilihan tindakan, dan memanfaatkan kapabilitas nasional untuk mencapai tujuan atas nama negara. Menurut Holsti, negara sebagai level analisis, berfokus pada ideologi, motivasi, cita-cita, persepsi, nilai-nilai, atau idiosinkretik dari pihak atau orang-orang yang mewakili atau dipilih untuk membuat keputusan bagi negara (Holsti dalam Afinotan, 2014:250). Perumusan sebuah kebijakan luar negeri akan disesuaikan dengan kepentingan nasional suatu negara (Jackson \& Sørensen, 2003:68). Inilah yang menyebabkan hubungan antara 
kebijakan luar negeri dan kepentingan nasional sangatlah erat (Sutch \& Elias, 2007:54).

Foreign policy decision making mengacu pada pilihan yang diambil oleh individu, kelompok, dan koalisi, yang mempengaruhi tindakan suatu negara dalam kancah internasional. Pengambilan sebuah kebijakan luar negeri sering kali ditandai dengan taruhan tinggi, ketidakpastian yang sangat besar, dan banyak resiko (Renshon \& Renshon, 2008:509). Mintz dan DeRouen (2010:15-18) mengklasifikasikan jenis-jenis keputusan luar negeri ke dalam bentuk keputusan tunggal (one-shot atau single decisions); keputusan interaktif (keputusan yang mempengaruhi dan dipengaruhi oleh keputusan aktor lain); keputusan berurutan (sequential decisions); keputusan interaktif yang berurutan (sequential-interactive decisions); dan keputusan kelompok. Pembuatan keputusan luar negeri dapat dilihat dari level analisis individual, kelompok, dan koalisi.

Menurut Mintz dan DeRouen (2010:97-130) ada empat faktor yang menentukan pengambilan suatu kebijakan luar negeri. Keempat faktor tersebut adalah sebagai berikut: pertama, decision environment, terdiri dari kendala waktu, kendala informasi, ambiguitas, keakraban, akuntabilitas, resiko, tekanan, pengaturan dinamis versus statis, dan pengaturan interaktif; kedua, faktor psikologis yakni kepribadian dan keyakinan dari para pemimpin, gaya kepemimpinan, emosi, citra atau images, konsistensi kognitif, dan penggunaan analogi pengaruh dan membentuk pengambilan keputusan luar negeri; ketiga, faktor internasional, seperti pencegahan (deterrence), perlombaan senjata, strategic surprise, pembentukan aliansi, dan regime type of the adversary; keempat, faktor domestik, seperti kondisi ekonomi (taktik pengalihan), kepentingan ekonomi, opini publik, siklus pemilu, dan two-level games.

Coplin (1992) mengemukakan bahwa para pembuat kebijakan luar negeri adalah sekelompok orang yang dihadapkan pada situasi-situasi tertentu, bertanggungjawabkepada pihaklain, ditekan olehberagam kondisi, dan diharuskan mengambil sebuah keputusan berdasarkan pilihan-pilihan tertentu. Para pembuat kebijakan dianggap sebagai pemecah masalah yang rasional, tidak bertindak sembarangan. Pengambilan keputusan oleh para pembuat kebijakan dalam politik internasional bisa dipandang sebagai proses intelektual, proses psikologis, dan proses organisasional.

\section{Kepentingan Nasional}

Menurut Morgenthau (dalam Kiyono, 1969:2-5), secara umum gagasan kepentingan nasional mengarah kepada hal yang berkaitan dengan kesejahteraan umum dan proses hukum. Ada dua faktor yang terkandung dalam gagasan kepentingan nasional yakni tuntutan secara rasional sesuai dengan kebutuhan serta hal yang dapat berubah yang ditentukan oleh situasi 
tertentu. Morgenthau menyatakan bahwa dalam dunia yang terdiri dari banyak negara yang saling bersaing dan bertentangan, keberlangsungan hidup adalah kebutuhan dasar mereka. Oleh karena itu, semua negara melakukan segala cara untuk melindungi identitas fisik, politik, budaya mereka agar tidak hilang atau tergerus oleh negara lain. Lebih lanjut, konsep kepentingan nasional tidak memprioritaskan dunia yang damai dan harmonis ataupun tidak menghindarkan adanya konflik, sebagai hasil dari pencapaian kepentingan nasional yang dilakukan oleh setiap negara. Sebaliknya, Morgenthau berasumsi bahwa konflik dan ancaman perang yang berkelanjutan, harus diminimalkan melalui penyesuaian kepentingan nasional yang bertentangan melalui tindakan diplomatik secara kontinu. Keberlangsungan hidup di antara bangsa-bangsa adalah elemen sentral dari kepentingan nasional, dimana elemen-elemen lain dirancang sesuai dengan keadaan yang melingkupinya.

Secara umum, terdapat dua aliran pemikiran dasar tentang pendefinisian kepentingan nasional. Aliran pertama berasal dari kalangan negarawan realisme yang diwakili oleh Otto von Bismarck pada abad ke-19 dan Richard Nixon pada abad ke-20. Mereka menyatakan bahwa kepentingan nasional harus didefinisikan dalam terminologi perhitungan kekuatan nyata negara (tangible power) dan lingkup pengaruhnya terhadap negara lain. Bentuk kekuatan nyata negara dapat dihitung dari kepemilikan meriam dan senapan, misil nuklir, dan senjata pembom, dimana tantangan utamanya adalah menjaga keseimbangan kekuatan militer yang menguntungkan negaranya. Aliran pemikiran lainnya, menyatakan bahwa kepentingan nasional harus didefinisikan secara lebih luas, mencakup nilai-nilai yang tak berwujud (intangible), tetapi sangat diperhitungkan, seperti hak asasi manusia, kebebasan hak-hak ekonomi, dan kebebasan dari wabah penyakit. Woodrow Wilson dan V.I. Lenin mewakili aliran ini. Kedua pemimpin ini menggunakan kekuatan militer negara mereka untuk mempromosikan nilai-nilai penentuan nasib secara nasional dan egalitarisme ekonomi (Miskel, 2002:97).

Perbedaan terminologi kepentingan nasional antara pendekatan realisme dan liberalisme berada dalam spektrum yang cukup luas. Kaum realis sepakat bahwa kebijakan luar negeri suatu negara hanya untuk memenuhi kepentingan nasional. Realisme memandang bahwa kepentingan nasional dan kebijakan luar negeri berada tataran perebuatan kekuasaan dan kelangsungan hidup negara (Jackson \& Sorensen, 2003:82). Hal ini menyebabkan hubungan antar negara cenderung lebih bersifat permusuhan atau kompetisi dibanding kerjasama (Manan, 2017:178). Kepentingan nasional utama dari negara adalah untuk mengejar keamanan negara, yang mendorong negara untuk memperkuat kekuatan militernya agar tetap dapat bertahan hidup dari ancaman negara lain (Dunne \& Schmidt 
2001:153). Bagi kaum realis, inti dari kepentingan nasional adalah bertahan hidup karena kepentingan lain seperti ekonomi, lingkungan hidup, dan kemanusiaan tidak akan tercapai jika keberadaan negara terancam (Dunne \& Schmidt, 2005:174).

Berbeda dengan realisme, kaum liberal berpendapat bahwa kepentingan nasional negara harusnya fokus pada pengejaran perdamaian, harmoni antar negara (Burchill, 2005:125). Dalam hubungan yang saling bergantung, negara-negara lebih menyukai kerjasama dibandingkan pertentangan dan berpikir dalam hal yang saling menguntungkan untuk kepentingan nasional mereka. Liberalisme menawarkan demokrasi dan pasar bebas sebagai cara untuk mencegah terjadinya perang (Burchill dalam Manan, 2017:179). Dalam siklus ketergantungan kompleks, kekuatan militer menjadi semakin kurang berguna dan kesejahteraan, bukan keamanan, menjadi tujuan utama dan perhatian negara dalam pencapaian kepentingan nasional mereka (Jackson \& Sørensen (2003), dalam Manan, 2017: 181).

Dalam mendefinisikan hubungan antara kepentingan nasional dan kebijakan luar negeri, Patten (2002:2-4) memiliki pemikiran yang berbeda dengan banyak ahli. Menurutnya, kepentingan nasional merupakan sebuah konsep lama yang telah memiliki arti yang baru. Pencapaian sebuah kepentingan nasional telah lama diterima luas sebagai satu-satunya tujuan jelas dari pembentukan kebijakan luar negeri. Akan tetapi, konsep kepentingan nasional bukan merupakan hal yang sederhana dan dalam perkembangannya menjadi semakin rumit. Menurut Patten, kepentingan nasional suatu negara seringkali justru dapat dikejar dengan lebih efektif jika pihak pembuat kebijakan luar negeri berhenti menganggapnya sebagai tujuan utama pembuatan sebuah kebijakan.

\section{Kebijakan Selektif (Selective Policy) Imigrasi Indonesia}

Sejarah mencatat bahwa Indonesia telah lama menjadi primadona masuknya warga asing. Pada zaman penjajahan, kekayaan sumber daya alam Indonesia yakni komoditas perkebunan yang memiliki nilai jual tinggi di pasar dunia membuat wilayah Indonesia menjadi rebutan negara-negara Eropa untuk dikuasai. Ketika dijajah oleh Pemerintah Hindia Belanda, kebijakan keimigrasian yang ditetapkan adalah politik pintu terbuka (opendeur politiek). ${ }^{1}$ Kebijakan ini membuka pintu seluas-luasnya bagi orang asing untuk masuk dan tinggal ke dalam wilayah Indonesia, serta menjadi warga Hindia Belanda. Ketika Indonesia telah memperoleh kemerdekaan, peraturan keimigrasian Pemerintah Hindia Belanda akhirnya dicabut dan diganti peraturan baru yang mendukung semangat kemerdekaan Indonesia

1 Politik pintu terbuka merupakan manifestasi kebijaksanaan imperialisme modern, menggantikan posisi cultuurstelsel yang merupakan manifestasi kebijaksanaan imperialisme tua (Bey, 2004: 86). 
(Direktorat Jenderal Imigrasi, tanpa tahun). Memasuki era globalisasi pada awal tahun 2000-an, tren migrasi antar negara yang semakin meningkat juga dirasakan oleh Negara Indonesia. Pada tahun 2016 melalui Peraturan Presiden Republik Indonesia Nomor 21 Tahun 2016 tentang Bebas Visa Kunjungan, Indonesia memasuki babak baru dalam bidang keimigrasian dimana diberikan kebebasan bagi orang asing dari 169 negara untuk masuk tanpa visa dengan tujuan kunjungan singkat atau berlibur. Jumlah orang asing yang masuk ke Indonesia meningkat secara signifikan.

Semua negara berdaulat pasti menjalankan fungsi pemeriksaan dan pengawasan kepada setiap warga negara asing yang hendak memasuki wilayah negaranya demi menegakan kedaulatan negara. Setiap warga negara asing yang hendak memasuki wilayah negara lain akan diseleksi dan dipilah. Hanya orang asing yang memenuhi syarat-syarat tertentu yang akan diizinkan untuk memasuki suatu wilayah negara berdasarkan kebijakan imigrasi masing-masing negara. Kebijakan pemilihan yang dilaksanakan secara selektif terhadap orang asing dalam bidang keimigrasian merupakan sebuah teori atau prinsip dasar yang pada dasarnya berlaku secara universal di semua negara, termasuk di Negara Indonesia.

Pemeriksaan dan pengawasan orang asing oleh Pemerintah Indonesia dijalankan berdasarkan fungsi keimigrasian Indonesia. Adapun fungsi keimigrasian Indonesia adalah fungsi pemerintahan negara dalam memberikan pelayanan keimigrasian, penegakan hukum, keamanan negara, dan fasilitator pembangunan kesejahteraan masyarakat (Pasal 1, UU RI Nomor 6 Tahun 2011 tentang Keimigrasian). Fungsi ini akan diterapkan kepada semua warga negara asing (WNA) sejak warga negara asing tersebut mengajukan permohonan izin memasuki wilayah Indonesia, pemeriksaan dokumen di tempat pemeriksaan imigrasi (TPI), selama berada, berkegiatan, dan bertempat tinggal di wilayah Negara Indonesia, hingga yang bersangkutan meninggalkan wilayah kedaulatan Negara Indonesia. Secara khusus, fungsi keimigrasian dijalankan oleh Direktorat Jenderal Imigrasi, Kementerian Hukum dan Hak Asasi Manusia Republik Indonesia, dengan berkoordinasi dengan kementerian dan lembaga negara terkait.

Kebijakan keimigrasian selektif (selective policy) Indonesia kepada warga negara asing secara khusus tercantum pada Undang-Undang Republik Indonesia Nomor 6 Tahun 2011 tentang Keimigrasian. Undangundang tersebut menjabarkan bahwa setiap orang asing yang akan masuk dan memperoleh izin tinggal di Indonesia harus sesuai dengan maksud dan tujuannya berada di Indonesia dengan tetap menjunjung tinggi nilainilai dan hak asasi manusia. Lebih lanjut, kebijakan selektif (selective policy) keimigrasian Indonesia memaparkan bahwa hanya orang asing yang memberikan manfaat serta tidak membahayakan keamanan dan ketertiban 
umum yang akan diperbolehkan masuk dan berada di Wilayah Negara Indonesia (Kementerian Hukum dan HAM RI, 2011). Penerapan selektif policy merupakan salah satu kepentingan nasional negara Indonesia dalam bidang keimigrasian untuk menjaga kedaulatan negara Indonesia dari ancaman yang mungkin akan dihadapi dengan masuknya orang asing.

Jika menilik kebijakan selektif (selective policy) imigrasi Indonesia maka ada dua elemen penting didalamnya yakni pendekatan keamanan (security approach) dan pendekatan kesejahteraan (prosperity approach) yang diharapkan bisa terpenuhi ataupun tidak terlanggar dengan masuknya orang asing ke dalam wilayah negara Indonesia. Dalam pelaksanaannya, keseimbangan antara kedua pendekatan ini harus tetap diperhatikan, satu pendekatan sama pentingnya dibanding pendekatan lainnya (Santoso, 2012:143). Kedua pendekatan ini berjalan seiring untuk menyeleksi setiap warga negara asing yang hendak masuk ke wilayah negara Indonesia.

Pendekatan keamanan (security approach) dalam kebijakan ini tidak hanya terkait dengan pendekatan keamanan tradisional yakni keamanan negara yang berkaitan dengan militerisasi dan konflik (Sudiar, 2019:152) sebagai bagian dari kedaulatan negara, tetapi berkaitan juga dengan keamanan non-tradisional yakni keamanan manusia (human security) dari warga negara Indonesia. Mendefinisikan pendekatan kesejahteraan (prosperity approach) akan sangat terkait dengan dimensi material yakni kedatangan orang asing dapat memberikan dampak positif bagi perekonomian negara Indonesia. Tetapi kesejahteraan disini bermakna luas, terkait dengan dimensi sosial dan psikologi yakni kemampuan untuk memberi dan menerima, mendapatkan penghargaan dan rasa hormat, berkontribusi pada pekerjaan yang bermanfaat, dan untuk memiliki rasa memiliki dan kepercayaan di masyarakat (Jackson, 2009:7). Singkatnya, bagaimana orang asing tersebut berpartisipasi secara bermakna dan positif dalam kehidupan masyarakat Negara Indonesia.

Selective policy keimigrasian Indonesia diterapkan kepada semua warga negara asing yang memasuki wilayah negara Indonesia tanpa terkecuali. Penerapan kebijakan ini didasarkan pada pemikiran bahwa tidak semua orang asing dari negara maju atau negara yang stabil dalam segi keamanan dapat mendatangkan manfaat kepada negara Indonesia. Sebaliknya, tidak semua orang asing dari negara miskin atau rawan jika memasuki wilayah Indonesia akan mendatangkan kerugian. Penyeleksian warga negara asing sangat vital untuk mencegah dampak negatif yang timbul dengan masuknya mereka ke wilayah Negara Indonesia.

\section{Penetapan Negara Calling Visa}

Tidak semua negara di dunia memiliki tingkat keamanan dan perekonomian yang stabil. Terdapat negara dimana pemerintahnya tidak 
mampu untuk mengendalikan kemiskinan maupun pergolakan keamanan dan pemberontakan dalam negeri sehingga tidak sanggup untuk memberikan perlindungan kepada warga negaranya sendiri. Selain itu, terdapat negara yang menutup diri dan memilih untuk membatasi interaksi dalam pergaulan komunitas internasional, selalu berkonflik dengan negara lain, ataupun memiliki banyak musuh karena terus-menerus mengeluarkan kebijakan luar negeri yang dianggap bertentangan dengan perdamaian dunia. Negara-negara ini dianggap rawan sehingga negara lain membatasi kedatangan warga negaranya. Pemerintah Indonesia menyebut negaranegara yang sesuai dengan klasifikasi di atas sebagai negara calling visa. Sebagai perwujudan dari selective policy dalam pengaturan keimigrasian, maka Pemerintah Indonesia menetapkan beberapa negara dalam kategori negara calling visa (Djati \& Christian, 2019:65).

Menurut Peraturan Menteri Hukum dan Hak Asasi Manusia Republik Indonesia Nomor M.Hh-01.Gr.01.06 Tahun 2012 tentang Tata Cara Penetapan Negara Calling Visa dan Pemberian Visa bagi Warga Negara dari Negara Calling Visa, negara calling visa adalah negara yang kondisi atau keadaan negaranya dinilai mempunyai tingkat kerawanan tertentu ditinjau dari aspek ideologi, aspek politik, aspek ekonomi, aspek sosial, aspek budaya, aspek pertahanan dan keamanan negara, dan aspek keimigrasian (Kementerian Hukum dan HAM RI, 2012). Pemerintah Indonesia memiliki kedaulatan untuk menetapkan sebuah negara masuk dalam klasifikasi negara calling visa. Secara khusus, penetapan negara yang masuk dalam kategori calling visa diwakili oleh Kementerian Hukum dan Hak Asasi Manusia Republik Indonesia. Untuk menetapkan negara-negara calling visa, Menteri Hukum dan Hak Asasi Manusia membentuk tim koordinasi penilai yang memberikan rekomendasi mengenai tingkat kerawanan negara tertentu, yang terdiri atas unsur-unsur: Kementerian Hukum dan Hak Asasi Manusia; Kementerian Dalam Negeri; Kementerian Luar Negeri; Kementerian Tenaga Kerja dan Transmigrasi; Kepolisian Negara Republik Indonesia; Kejaksaan Agung; Badan Intelijen Negara; Badan Intelijen Strategis Tentara Nasional Indonesia; dan Badan Narkotika Nasional (Pasal 2 Permenkumham RI No. M.Hh-01.Gr.01.06 tahun 2012).

Penetapan negara-negara calling visa dilakukan dengan kajian mendalam terhadap kondisi negara tersebut berdasarkan pendefinisian tujuan, pilihan tindakan, dan memanfaatkan kapabilitas nasional untuk mencapai kepentingan nasional seperti yang telah diuraikan oleh K.J. Holsti. Jenis keputusan luar negeri ini merupakan keputusan kelompok yang terdiri dari tim koordinasi atas nama negara demi mencapai tujuan kepentingan nasional Indonesia. Dalam hal ini, kepentingan nasional negara Indonesia sangat erat kaitannya dengan selective policy dimana hanya orang yang bermanfaat (prosperity approach) dan tidak membahayakan 
keamanan dalam negeri (security approach) yang akan diizinkan untuk memasuki wilayah negara Indonesia. Sebagai salah satu perwujudan dari selective policy dalam fungsi keimigrasian Indonesia, beberapa negara yang dianggap memiliki tingkat kerawanan tertentu dimasukan dalam kategori negara calling visa (Djati \& Christian, 2019:65).

Dalam perkembangannya, jika kondisi faktor domestik dan internasional, serta kerawanan negara-negara calling visa mengalami perubahan ke arah yang lebih stabil, maka status negara calling visa dapat dicabut. Hal ini terjadi pada Negara Irak, Iran, dan Pakistan yang sebelumnya pernah masuk dalam kategori negara calling visa. Pencabutan status calling visa ini sangat erat dengan kepentingan nasional Indonesia. Pada tahun 1995 negara calling visa berjumlah 38 (Keputusan Menteri Kehakiman No. M.01-IZ.01-10 tahun 1995). Seiring perkembangan kondisi domestik negara calling visa tersebut dan kepentingan nasional Indonesia, jumlah ini mengalami pengurangan. Berdasarkan Permenkumham No. M.HH-02.GR.01.06 Tahun 2017 tentang Perubahan Ketiga Atas Keputusan Menteri Hukum dan Ham Nomor M.HH-01.GR.01.06 tahun 2012 tentang Tata Cara Penetapan Negara Calling Visa dan Pemberian Visa bagi Warga Negara dari Negara Calling Visa, negara-negara yang masih termasuk dalam kategori negara calling visa menjadi sembilan negara. Adapun kesembilan negara tersebut adalah sebagai berikut: Afganistan, Guinea, Israel, Korea Utara, Kamerun, Liberia, Niger, Nigeria, dan Somalia.

\section{Anomali Penentuan Negara Calling Visa}

Penetapan negara calling visa merupakan kebijakan Indonesia yang dibuat dengan mempertimbangkan kondisi negara tertentu yang dianggap rawan. Klasifikasi rawan ditinjau dari aspek ideologi, aspek politik, aspek ekonomi, aspek sosial, aspek budaya, aspek pertahanan dan keamanan negara, maupun aspek keimigrasian. Pertanyaan kemudian timbul sehubungan dengan penentuan status rawan tersebut. Aspek kerawanan ekonomi serta pertahanan dan keamanan negara merupakan aspek yang paling mudah untuk dinilai. Jika mengacu pada kerawanan keamanan, maka negara-negara yang sering berkonflik sehingga menyebabkan banyak warga negaranya akhirnya mencari suaka atau menjadi pengungsi ke negara lain, perlu diperhitungkan. Afganistan, Somalia, dan Irak layak dimasukan dalam kategori negara rawan karena menurut data perwakilan United Nations High Commissioner for Refugees di Indonesia, pengungsi terbanyak di Indonesia sampai akhir Desember 2017 berasal dari negara tersebut (UNHCR, 2017). Faktanya, walaupun Irak pernah masuk dalam kategori negara calling visa, tetapi pada tahun 2013 statusnya telah dicabut meskipun jumlah pengungsi dari Negara Irak masih terus membanjiri Negara Indonesia. Negara Suriah yang dapat dikategorikan rawan dari 
segi pertahanan dan keamanan, juga tidak masuk ke dalam daftar negara calling visa. Negara-negara rawan dari aspek ekonomi dengan Gross National Income (GNI) per kapita terendah di dunia, seperti Republik Afrika Tengah, Burundi, Republik Demokratik Kongo, Malawi, dan Mozambik (World Population Review, 2019) tidak masuk dalam kategori negara calling visa.

Pertanyaan juga muncul dengan status Israel dalam kategori negara caling visa. Israel tidak memiliki tingkat kerawanan atau instabilitas jika ditinjau dari aspek ideologi, politik, ekonomi, sosial, budaya, pertahanan dan keamanan negara, dan keimigrasian. Penetapan Israel sebagai negara calling visa dilakukan karena konteks internasional yakni elemen politis. Israel ditetapkan sebagai negara calling visa karena Israel tidak mengakui kedaulatan Negara Palestina, di mana hal ini bertentangan dengan kepentingan nasional Negara Indonesia, yang memiliki hubungan diplomatik yang erat dengan Palestina dan pengakuan kemerdekaan Palestina selalu menjadi prioritas kebijakan luar negeri Indonesia. Israel akan tetap masuk dalam kategori negara calling visa hingga Israel mau mengakui kemerdekaan dan kedaulatan Palestina.

Pakistan, sebagai salah satu negara yang sering berkonflik, pernah masuk dalam daftar negara calling visa. Kebijakan mencabut status calling visa Negara Pakistan pada tahun 2017 dipengaruhi oleh faktor decision environment (keakraban), faktor psikologis (keyakinan para pemimpin), dan faktor domestik (kepentingan ekonomi), seperti argumen Mintz dan DeRouen pada penjelasan sebelumnya. Faktor decision environment yakni hubungan diplomatik yang erat dan sama-sama tergabung dalam Organisasi Kerja Sama Islam (OKI), memegang peran penting dalam pencabutan status ini. Perwakilan Negara Pakistan secara kontinu meminta kepada Pemerintah Indonesia untuk mengeluarkan Pakistan dari kelompok negara calling visa dan telah mengajukan permohonan bebas visa kunjungan (BVK) sejak bulan Maret 2016 (Republika, 2017).

Keakraban yang terjadi antara Pemerintah Negara Indonesia dan Pemerintah Negara Pakistan kemudian memberikan keyakinan kepada para Pemimpin Indonesia bahwa kondisi Negara Pakistan tidak lagi membahayakan kepentingan nasional Indonesia. Akhirnya, kepentingan Indonesia dalam bidang ekonomi menguatkan niat Pemerintah Indonesia untuk mencabut status calling visa dari Negara Pakistan. Besarnya jumlah wisatawan dari Pakistan yang datang ke Indonesia pada tahun 2016, ketika Pakistan masih menjadi negara calling visa, membantu pembentukan citra positif terhadap negara tersebut meski proses pengajuan visa relatif lama dan rumit (Smartlegal, 2019). Pakistan diprediksi memiliki prospek yang akan bermanfaat bagi Indonesia ke depan. Status calling visa akan sangat menyulitkan bagi warga negara Pakistan untuk memasuki wilayah Negara Indonesia. Persyaratan yang harus dipenuhi warga negara calling visa dianggap terlalu berat, cukup rumit, dan menghabiskan waktu yang relatif 
lama (Kompas, 2017), sehingga diperkirakan akan mengurangi wisatawan serta penanam modal dari Pakistan yang ingin berinvestasi di Indonesia.

\section{Pemberian Izin Berkunjung kepada Orang Asing dari Negara Caling Visa}

Setiap orang asing yang hendak melakukan perjalanan ke wilayah Negara Indonesia wajib memiliki izin tertulis yang sah dan masih berlaku untuk melakukan kunjungan, kecuali yang dibebaskan dari kewajiban berdasarkan undang-undang. Izin tertulis tersebut dinamakan Visa Republik Indonesia. Undang-Undang Republik Indonesia Nomor 6 Tahun 2011 tentang Keimigrasian menyatakan bahwa Visa Republik Indonesia adalah keterangan tertulis yang diberikan oleh pejabat yang berwenang di Perwakilan Republik Indonesia atau di tempat lain yang ditetapkan oleh pemerintah Indonesia yang memuat persetujuan bagi orang asing untuk melakukan perjalanan ke wilayah Indonesia dan menjadi dasar untuk pemberian izin tinggal. Pemberian izin berkunjung ini dilakukan berdasarkan peraturan keimigrasian Indonesia dan disesuaikan dengan maksud dan tujuan dari orang asing memasuki wilayah Indonesia. Hal ini merupakan salah satu wujud penerapan selective policy imigrasi yang menjadi kepentingan nasional Indonesia (Kementerian Hukum dan HAM RI, 2011).

Orang asing dari negara calling visa wajib memiliki izin tertulis atau visa jika ingin memasuki wilayah Indonesia. Perizinan ini bisa didapatkan melalui proses pemberian izin calling visa di mana tahapannya akan memakan waktu yang lebih lama dibandingkan dengan proses pengurusan orang asing yang tidak masuk dalam kategori negara calling visa (Osda, 2019). Penerapan selective policy dilakukan jauh lebih ketat dan melalui proses berlapis. Perbedaan terbesar dari pemberian visa atau izin masuk kepada orang asing dari negara biasa dibandingkan dengan orang asing dari negara calling visa adalah pengajuan visa orang asing dari negara calling visa mewajibkan tahapan tertentu yaitu rekomendasi dari tim koordinasi penilai negara calling visa untuk mempertimbangkan kelayakan permohonan visa yang diajukan (Djati \& Christian, 2019:65). Rekomendasi dari tim koordinasi, yang ditentukan melalui rapat Clearance House $(\mathrm{CH})$, akan menjadi dasar keputusan dari Pemerintah Indonesia, secara khusus Direktur Jenderal Imigrasi, dalam memberikan persetujuan atau penolakan permohonan visa yang bersangkutan. Proses rekomendasi dari tim koordinasi inilah yang membuat permohonan izin masuk orang asing dari negara calling visa menjadi rumit dan menghabiskan waktu pengurusan yang lama.

Elemen penting lainnya dalam pemberian izin masuk bagi warga negara dari negara calling visa ada unsur penjamin, yakni orang ataupun perusahaan yang bertanggung jawab atas keberadaan orang asing selama 
berada di Indonesia. Penjamin orang asing dari negara calling visa yang merupakan orang/perorang berkewarganegaraan Indonesia dan harus berdomisili di Indonesia, sedangkan untuk perusahaan wajib berbadan hukum resmi. Untuk penjamin yang berasal dari perusahaan berbadan hukum, maka penjamin tersebut merupakan pimpinan perusahaan yang bersangkutan. Pada tahapan penelitian dan penilaian kelayakan orang asing dari negara calling visa untuk mendapatkan izin masuk ke Indonesia, tim koordinasi akan melakukan wawancara langsung dengan penjamin dalam rapat tim. Setiap permohonan visa orang asing dari negara calling visa akan mempertimbangkan kelayakan dan manfaat masuknya orang asing tersebut ke wilayah Indonesia.

Jika permohonan visa telah mendapat persetujuan dari tim koordinasi, pemberian izin masuk atau visa untuk orang asing dari negara calling visa dapat diberikan untuk sekali ataupun beberapa kali perjalanan. Apabila visa telah diberikan, tidak menjadi jaminan orang asing tersebut secara otomatis akan diizinkan masuk ke Indonesia. Pemeriksaan ketat di Tempat Pemeriksaan Imigrasi akan dilakukan terhadap paspor kebangsaan yang bersangkutan, surat penjamin, tiket kembali atau terusan, surat undangan/ pemberitahuan untuk kegiatan konferensi/pelatihan, rekomendasi instansi terkait mengenai penanaman modal atau investasi untuk tujuan investasi, ataupun rekomendasi Badan Intelijen Strategis Tentara Nasional Indonesia jika kegiatan dilakukan di daerah konflik yang membahayakan keberadaan dan keamanan orang asing. Permohonan visa bagi orang asing dari negara calling visa yang tidak memiliki hubungan diplomatik dengan Negara Indonesia, seperti Israel, hanya dapat diajukan pada Perwakilan Republik Indonesia di Bangkok dan Singapura. Visa ini tidak dapat diperpanjang dan tidak boleh dipergunakan untuk keperluan bekerja di Indonesia. Selain itu, orang asing tersebut hanya boleh masuk ke Indonesia melalui Tempat Pemeriksaan Imigrasi tertentu yakni Bandar Udara Soekarno-Hatta, Jakarta, atau di Bandar Udara Ngurah Rai, Bali (Kedutaan Besar Republik Indonesia di Singapura, 2018).

\section{Pengawasan dan Tindakan Administrasi Keimigrasian Indonesia}

Masuknya orang asing ke wilayah Indonesia dengan berbagai tujuan dan kepentingan memberikan efek beragam di segala bidang. Pengaruh yang terjadi pun tidak hanya berdampak positif tetapi juga terkadang mendatangkan efek negatif. Salah satu dampak negatif yang timbul dengan banyaknya orang asing yang masuk ke wilayah Negara Indonesia adalah meningkatnya pelanggaran keimigrasian (Ichwan \& Samiudin, 2019:2). Pemberian izin masuk kepada warga asing dari negara calling visa dilandaskan pada prinsip bahwa orang asing tersebut mampu mendatangkan dampak positif bagi pendapatan devisa negara dan tidak 
akan mengancam keamanan dan ketertiban masyarakat sesuai dengan maksud dari penerapan selective policy yang menjadi landasan kebijakan keimigrasian Pemerintah Indonesia. Untuk meminimalisir dampak negatif dengan kedatangan orang asing, fungsi pengawasan harus dilakukan dengan maksimal demi menegakan kedaulatan Negara Indonesia.

Pengawasankeimigrasianadalahserangkaiankegiatanyangdilakukan untuk mengumpulkan, mengolah, serta menyajikan data dan informasi keimigrasian warga negara Indonesia dan orang asing dalam rangka memastikan dipatuhinya ketentuan peraturan perundang-undangan di bidang keimigrasian (Pasal 1 angka 2 Peraturan Pemerintah Nomor 4 Tahun 2017 tentang Tata Cara Pengawasan Keimigrasian). Sistem pengawasan keimigrasian meliputi pengawasan administrasi seperti pemeriksaan surat perjalanan, surat atau dokumen lain, pemotretan, pengambilan sidik jari, dan pengelolaan data keimigrasian di tempat pemeriksaan imigrasi, kantor imigrasi, maupun perwakilan Republik Indonesia di luar negeri dan Direktorat Jenderal Imigrasi, serta pengawasan lapangan atau operasional, seperti pemantauan atau penyelidikan secara wawancara, pengamatan dan penggambaran, pengintaian, penyadapan, penggunaan informasi, dan kegiatan lain (Ichwan \& Samiudin, 2019:11-12).

Pengawasan administrasi bagi orang asing dari negara calling visa dilakukan lebih ketat dan selektif. Sedangkan sistem pengawasan lapangan bagi orang asing dari negara calling visa yang ada di wilayah Indonesia, dilakukan sama seperti pengawasan orang asing pada umumnya yakni melalui kegiatan pemantauan dan operasi pemantauan. Pengawasan lapangan ini dilakukan dengan ketat di tempat-tempat orang asing berada seperti hotel dan penginapan, pusat keramaian, dan tempat hiburan (Ichwan \& Samiudin, 2019:28). Jika terbukti melanggar, maka orang asing tersebut dapat dikenakan tindakan administrasi keimigrasian. Tindakan administratif keimigrasian dikenakan terhadap orang asing di wilayah Indonesia karena melakukan kegiatan berbahaya yang diduga mengganggu ketertiban umum atau tidak menghormati dan melanggar peraturan peundang-undangan yang berlaku di Indonesia (Wulandari \& Andaryadi, 2019:5).

Jenis-jenis tindakan administrasi keimigrasian yang dapat dikenakan kepada setiap orang asing, termasuk orang asing dari negara calling visa, adalah sebagai berikut: pencantuman dalam daftar pencegahan (larangan untuk keluar wilayah Indonesia) atau penangkalan/cekal (larangan untuk masuk wilayah Indonesia); pembatasan, perubahan, atau pembatalan izin tinggal; larangan untuk berada di satu atau beberapa tempat tertentu di wilayah Indonesia; keharusan untuk bertempat tinggal di suatu tempat tertentu di wilayah Indonesia; pengenaan biaya beban; dan deportasi atau tindakan paksa mengeluarkan orang asing dari wilayah Negara Indonesia (Wulandari \& Andaryadi, 2019:10-20). 


\section{Kesimpulan}

Selective policy merupakan kebijakan yang menjadi dasar pelaksanaan imigrasi Indonesia terhadap orang asing yang hendak memasuki wilayah Indonesia. Prinsip dasar kebijakan ini tercantum pada Undang-Undang Republik Indonesia Nomor 6 Tahun 2011 tentang Keimigrasian. Prinsip selective policy yakni memilah setiap warga negara asing yang hendak memasuki wilayah Indonesia, hanya orang asing yang memberikan manfaat serta tidak membahayakan keamanan dan ketertiban umum yang akan diperbolehkan masuk dan berada di wilayah Negara Indonesia. Tujuan dari penerapan kebijakan ini adalah untuk menjaga kepentingan nasional Indonesia yakni kedaulatan dan keamanan Indonesia yang mungkin akan terancam jika orang asing dibiarkan masuk dengan bebas. Selective policy imigrasi Indonesia didasarkan pada pendekatan keamanan (security approach) dan pendekatan kesejahteraan (prosperity approach) yang berjalan secara seimbang.

Penerapan selective policy dilakukan dengan jauh lebih ketat dan selektif terhadap orang asing yang berasal dari negara calling visa. Hal ini disebabkan kondisi negara calling visa yang dianggap rawan ditinjau dari aspek ideologi, aspek politik, aspek ekonomi, aspek sosial, aspek budaya, aspek pertahanan dan keamanan negara, dan aspek keimigrasian. Hingga saat ini ada sembilan negara yang masuk dalam kategori negara calling visa yakni Afganistan, Guinea, Israel, Korea Utara, Kamerun, Liberia, Niger, Nigeria, dan Somalia. Penetapan negara calling visa merupakan kebijakan luar negeri Negara Indonesia dengan mempertimbangkan rekomendasi dari tim koordinasi penilai yang dibentuk oleh Pemerintah Indonesia dan menyesuaikan kepentingan nasional Indonesia.

Orang asing dari negara calling visa harus mendapatkan izin melalui proses pemberian izin calling visa di mana tahapannya akan memakan waktu yang lebih lama dibandingkan dengan pengurusan biasa, jika ingin berkunjung ke Indonesia. Orang asing tersebut wajib memperoleh rekomendasi dari tim koordinasi penilai negara calling visa yang akan mempertimbangkan kelayakan permohonan visa yang diajukan. Yang bersangkutan harus memiliki penjamin dari unsur orang/perorang yang berkewarganegaraan Indonesia dan berdomisili di wilayah Indonesia atau perusahaan berbadan hukum resmi. Keberadaan orang asing dari negara calling visa akan diawasi oleh Pemerintah Indonesia. Pengawasan ketat ini meliputi pengawasan administrasi dan serta pengawasan lapangan atau operasional. Jika melanggar, yang bersangkutan akan dikenakan tindakan administratif keimigrasian yang disesuaikan dengan tingkatan berat pelanggarannya. 


\section{Daftar Pustaka}

Afinotan, L.A. (2014). Decision Making in International Relations: A Theoretical Analysis. Canadian Social Science, 10(5), pp. 249-256.

Arifin, R. (2018). Penolakan Orang Asing ke Indonesia melalui Tempat Pemeriksaan Imigrasi Di Bandara Internasional: Sebuah Kedaulatan Absolut. Jurnal Kajian Keimigrasian, 1(1), pp. 151-165.

Azam, J.P., \& F. Gubert. (2006). Migrants' Remittances and the Household in Africa: A Review of the Evidence. Journal of African Economies, 15, AERC Supplement 2, pp. 426-462.

Belarminus, R. (2017) Data Imigrasi: Sepanjang 2017, Warga China Paling Banyak Masuk Ke Indonesia [Online]. Tersedia dalam: <https://www. tribunnews.com/nasional/2017/07/05/data-imigrasi-sepanjang-2017warga-china-paling-banyak-masuk-ke-indonesia> [diakses 22 Januari 2020].

Bey, I.S. (2004). Hentikan Revisi UUPA 1960 untuk Neoimperialisme!!! Jurnal Analisis Sosial, 9(1), pp. 85-95.

Burchill, S. (2005). The National Interest in International Relations Theory. New York: Palgrave Macmillan.

Castles, S., De Hass, H., \& Miller, M.J. (2014). The Age of Migration: International Population movements in the modern world. New York: The Guilford Press.

Chaika, M., \& De Haas, H. (2014). The Globalization of Migration: Has the Wolrd Become More Migratory? International Migration Review, 48(2), pp. 283-323.

Coplin, W.D. (1992). Introduction to International Politics. Edisi Bahasa Indonesia Pengantar Politik Internasional: Suatu Telaah Teoritis edisi ke-2. Bandung: Sinar Baru.

Direktorat Jenderal Imigrasi Kementerian Hukum dan HAM Republik Indonesia (tanpa tahun) Sejarah [Online]. Tersedia dalam: <http:// www.imigrasi.go.id/index.php/profil/sejarah> [diakses 23 Januari 2020].

Djati, W.K., \& Christian, C. (2019). Pemeriksaan Penerbitan Persetujuan Visa Republik Indonesia: Modul Pelatihan Fungsional Analis Keimigrasian Ahli Pertama. Depok: Badan Pengembangan Sumber Daya Manusia Hukum dan HAM (BPSDM).

Dunne, T., \& Schmidt, B.C. (2005). 'Realism'. In: John Baylis and Steve Smith (eds.), The Globalization of World Politics: An Introduction to International Relations. Third Edition. Oxford: Oxford University Press.

Gusnelly (2010). Migrasi, Kewarganegaraan, dan Partisipasi Imigran: Studi Kasus Imigran Turki di Belanda. Jurnal Kajian Wilayah, 1(1), pp. 59-78.

Ichwan, N., \& Samiudin (2019). Pengawasan Keimigrasian. Depok: Badan Pengembangan Sumber Daya Manusia Hukum dan Ham (BPSDM). 
Jackson, R., \& Sørensen, G. (2003). Introduction to International Relations: Theories and Approaches, Second Edition. Oxford: Oxford University Press.

Jaramaya, R., \& Maharani, E. (2017). Pemerintah Indonesia Hapus Status Calling Visa Pakistan [Online]. Tersedia dalam: <https:// nasional.republika.co.id/berita/nasional/umum/17/08/07/oub1cf335pemerintah-indonesia-hapus-status-calling-visa-pakistan> [diakses 31 Januari 2020].

Kedutaan Besar Republik Indonesia di Singapura (2018) Calling Visa bagi WNA dari Negara Calling Visa [Online]. Tersedia dalam: <https:// kemlu.go.id/singapore/id/pages/calling_visa_bagi_wna_dari_ negara_calling_visa/167/about-service> [diakses 30 Maret 2020].

Kementerian Hukum dan HAM RI (2011). Undang-Undang Republik Indonesia Nomor 6 Tahun 2011 tentang Keimigrasian.

Kementerian Hukum dan HAM RI (2012). Peraturan Menteri Hukum dan Hak Asasi Manusia Republik Indonesia Nomor M.HH-01.GR.01.06 Tahun 2012 Tentang Tata Cara Penetapan Negara Calling Visa dan Pemberian Visa bagi Warga Negara dari Negara Calling Visa.

Kiyono, K. (1969). A Study on the Concept of the National Interest of Hans J. Morgenthau: As the Standard of American Foreign Policy. Nagasaki University's Academic Output SITE, 49(3), pp. 1-20.

Kompas (2017) Kebijakan Calling Visa untuk Pakistan [Online]. Tersedia dalam: <https://nasional.kontan.co.id/news/kebijakan-calling-visauntuk-pakistan> [diakses 30 Januari 2020].

Laucereno, S.F. (2019). 14,4 Juta Turis Asing Masuk RI, Paling Banyak dari Malaysia [Online]. Tersedia dalam: <https://finance.detik.com/beritaekonomi-bisnis/d-4367885/144-juta-turis-asing-masuk-ri-palingbanyak-dari-malaysia> [diakses 10 Februari 2020].

Li, P.S. (2008). World Migration in the Age of Globalization: Policy implications and challenges. New Zealand Population Review, 33(34), pp. 1-22.

Manan, M. (2017). Foreign Policy and National Interest: Realism and Its Critiques. Global E Strategis, 9(2), pp. 175-189.

Mintz, A. \& DeRouen K.Jr. (2010). Understanding Foreign Policy Decision Making. Cambridge: Cambridge University Press.

Mir, U.R., Hassan, S.M., \& Qandri, M.M. (2014). Understanding Globalization and its Future: An Analysis. Pakistan Journal of Social Sciences (PJSS), 34(2), pp. 607-624.

Miskel, J.F. (2002). National Interests: Grand Purposes or Catchphrases?. Naval War College Review, 55(4), pp. 95-104.

Osda, D. (2019). Negara-negara yang Masuk ke Daftar Clearance House Indonesia [Online]. Tersedia dalam: <https://www. 
goodnewsfromindonesia.id/2019/01/17/negara-negara-yang-masukke-dalam-daftar-clearance-house-indonesia> [diakses 5 Februari 2019].

Patten, C.F. (2002). Sovereignty and the National Interest - Old Concepts, New Meaning. Dublin: The Newman Lecture University College.

Peraturan Menteri Hukum dan Hak Asasi Manusia Republik Indonesia Nomor M.HH-02.GR.01.06 Tahun 2017 Tentang Perubahan Ketiga Atas Keputusan Menteri Hukum dan Ham Nomor M.HH-01.GR.01.06 Tahun 2012 Tentang Tata Cara Penetapan Negara Calling Visa dan Pemberian Visa bagi Warga Negara dari Negara Calling Visa.

Renshon, J., \& Renshon, S.A. (2008). The Theory and Practice of Foreign Policy Decision Making. Political Psychology, 29(4), pp. 509-536.

Romdiati, H. (2015). Globalisasi Migrasi dan Peran Diaspora: Suatu Kajian Pustaka. Jurnal Kependudukan Indonesia, 10(2), pp. 89-100.

Santoso, M.I. (2012). Perspektif Imigrasi dalam Migrasi Manusia. Bandung: Pustaka Reka Cipta.

Smart Legal (2019) Begini Kewajiban Clearance House Indonesia untuk Negara-negara Tertentu [Online]. Tersedia dalam: $<$ https://smartlegal. $\mathrm{id} /$ smarticle/2019/01/11/kewajiban-clearance-house-indonesia-untuknegara-negara-tertentu/> [diakses 17 Februari 2020].

Steger, M. B. (2003). Globalization: A Very Short Introduction. New York: Oxford University Press Inc.

Sudiar, S. (2019). Pendekatan Keamanan Manusia dalam Studi Perbatasan Negara. Jurnal Hubungan Internasional, 7(2), pp. 152-160.

Sutch, P., \& Elias, J. (2007). International Relations: The Basics. London: Routledge.

Syahrin, M. A. (2016). Menakar Kedaulatan Negara dalam Perspektif Keimigrasian. Jurnal Penelitian Hukum De Jure, 18(1), pp. 43-57.

UNHCR Indonesia (tanpa tahun). UNHCR di Indonesia [Online]. Tersedia dalam: <https://www.unhcr.org/id/unhcr-di-indonesia> [diakses 3 Februari 2020].

World Population Review (2019). Poorest Countries in the World 2019 [Online]. Tersedia dalam: <http://worldpopulationreview.com/ countries/poorest-countries-in-the-world/> [diakses 10 Februari 2020].

Wulandari, E., \& Andaryadi, S. (2019). Tindakan Administratif Keimigrasian. Depok: Badan Pengembangan Sumber Daya Manusia Hukum dan Ham (BPSDM). 